\title{
Article \\ Morphological, Molecular Identification and Pathogenicity of Neoscytalidium dimidiatum Causing Stem Canker of Hylocereus polyrhizus in Southern Thailand
}

\author{
Kim Sreang Dy ${ }^{1}$, Prisana Wonglom ${ }^{2}$, Chaninun Pornsuriya ${ }^{1}$ and Anurag Sunpapao ${ }^{1, * \mathbb{D}}$ \\ 1 Agricultural Innovation and Management Division (Pest Management), Faculty of Natural Resources, \\ Prince of Songkla University, Hatyai 90110, Songkhla, Thailand; dykimsreang168@gmail.com (K.S.D.); \\ chaninun.p@psu.ac.th (C.P.) \\ 2 Faculty of Technology and Community Development, Thaksin University, \\ Pa Payom 93210, Phatthalung, Thailand; prisana.w@tsu.ac.th \\ * Correspondence: anurag.su@psu.ac.th
}

check for updates

Citation: Dy, K.S.; Wonglom, P.; Pornsuriya, C.; Sunpapao, A. Morphological, Molecular Identification and Pathogenicity of Neoscytalidium dimidiatum Causing Stem Canker of Hylocereus polyrhizus in Southern Thailand. Plants 2022, 11, 504. https://doi.org/10.3390/ plants11040504

Academic Editors: Rafał Ogórek and Agata Piecuch

Received: 26 January 2022 Accepted: 9 February 2022 Published: 12 February 2022

Publisher's Note: MDPI stays neutral with regard to jurisdictional claims in published maps and institutional affiliations.

Copyright: (C) 2022 by the authors. Licensee MDPI, Basel, Switzerland. This article is an open access article distributed under the terms and conditions of the Creative Commons Attribution (CC BY) license (https:// creativecommons.org/licenses/by/ $4.0 /)$.

\begin{abstract}
Red-fleshed dragon fruit (Hylocereus polyrhizus) is commonly cultivated in Thailand, especially in southern Thailand, where the weather favors plant growth and development. In 2021, stem canker of $H$. polyrhizus was observed in a dragon fruit plantation field in Phatthalung Province, southern Thailand. Small, orange circular spots developed on the stem of H. polyrhizus, which later became gray, and the lesion expanded with a mass of conidia. Scytalidium-like fungus was isolated from infected tissues. Based on morphology and phylogenetic analyses of internal transcribed spacer (ITS), nuclear large subunit (LSU) and $\beta$-tubulin $(t u b)$ sequences of fungal isolates, the fungus was identified as Neoscytalidium dimidiatum. Pathogenicity tests revealed that this isolate caused stem canker on the stem of $H$. polyrhizus, similar to that observed in the field. Knowledge of the diagnosis of plant diseases is an important step for managing plant diseases and therefore, this finding provides basic information for the development of appropriate strategies to manage stem canker disease on H. polyrhizus plants.
\end{abstract}

Keywords: morphology; molecular identification; pathogenicity test; pitaya

\section{Introduction}

Dragon fruit (Hylocereus spp.) is native to Latin America's tropical and subtropical forest regions, including North, Central, and South America. Dragon fruit, of the genus Hylocereus, belongs to the Cactaceae family of climbing cactus [1] and is known by several names, including pitaya, pitahaya, and strawberry pear. Dragon fruit enriched with micronutrients is in high demand and is being promoted as a healthy fruit [2]. Currently, dragon fruit is classified into one of three varieties: H. polyrhizus; H. undatus; or Selenicereus megalanthus [3]. The suitability of a tropical climate, rainfall requirements, and soil types may have contributed to the growth of dragon fruit, especially red-fleshed dragon fruit [3].

Due to increased planting areas and high demand, dragon fruit in many crops attract disease and pests. Several diseases have been reported to negatively affect dragon fruit plantations and production [4]. Disease caused by fungi is a major problem for dragon fruit plantations worldwide [3,5]. For instance, the fungus Colletotrichum gloeosporioides was found to cause anthracnose on dragon fruit in Malaysia [3]. The fungi Neoscytalidium dimidiatum and Bipolris sp. have been reported to cause canker and bipolaris black spot, respectively, on dragon fruit in Vietnam [5]. Furthermore, the fungus Gilbertella persicaria was recently reported to cause flower rot on red-fleshed dragon fruit in Thailand [6].

Dragon fruit is an economically important crop that can support additive income for many households in Thailand. Saradhuldhat et al. [7] demonstrated that dragon fruit could grow in practically any type of soil, both upland and lowland in Thailand, and 
they are distributed throughout Thailand. Thailand is located in tropical and subtropical regions where the weather favors disease spread [8,9]. Several emerging diseases have been isolated and reported to cause diseases in several plant species in this area in the past 5 years [10-17]. However, the identification of fungal pathogens causing diseases on H. polyrhizus in Thailand is rarely documented. During 2021, stem canker of red-fleshed dragon fruit (H. polyrhizus) was observed in a cultivation field in Phatthalung Province, southern Thailand. Therefore, this research aimed to identify pathogens causing stem canker in Thailand based on morphology, molecular properties, and pathogenicity tests.

\section{Results}

\subsection{Symptom Observation}

Sunken brown necrosis was observed on the stems of $H$. polyrhizus at the cultivation field in Phatthalung Province, southern Thailand (Figure 1a). The whitish-yellow spots turned orange to brown with age. The spots coalesced to form larger spots or lesions and were surrounded by yellow halos (Figure 1b,c). The spots turned into necrotic water-soaked lesions and produced black pycnidia on the stem of $H$. polyrhizus (Figure 1d,e). The fungus was directly isolated and cultured on PDA for further study.
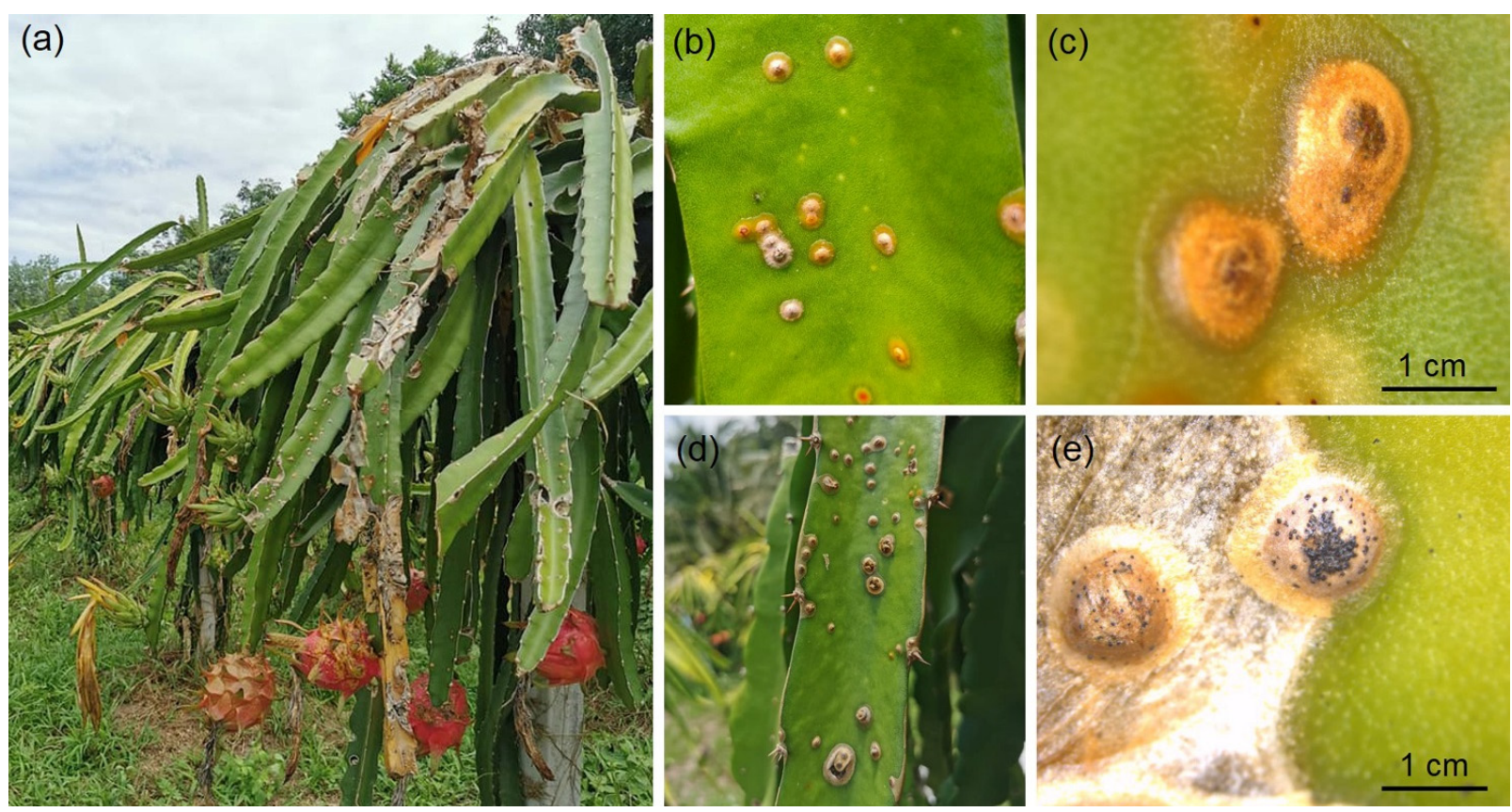

Figure 1. Stem canker of Hylocereus polyrhizus in the field (a), whitish-yellow spots, coalesced to form larger spots or lesions (b), spots or lesions surrounded by yellow halos (c), black pycnidia on stem of H. polyrhizus (d,e).

\subsection{Morphology of Fungal Isolate}

The fungal isolate PSU-SC02 obtained from PDA stock in Section 2.1 showed hairy colonies and olive-green to grayish colonies with dark gray to black pigmentation on PDA (Figure 2a-c). PSU-SC02 reached a diameter of $9 \mathrm{~cm}$ on PDA plates within 3 days, and the growth rate was $3 \mathrm{~cm} /$ day. The morphology of the PSU-SC02 isolate showed Scytalidium-like fungus. The hyphae were brown, branched, septate, and constricted into spore chains before disarticulation into arthroconidia. The arthroconidia were ellipsoid to ovoid in shape and hyaline to dark brown with thick walls and septate arthrospores, 3.1-18.0 $\mu \mathrm{m}$ long $\times 3.8-10.3 \mu \mathrm{m}$ wide $(n=20$, av $=10.0 \pm 3.7 \times 5.4 \pm 1.8) \mu \mathrm{m}$ (Figure 2e) Pycnidia had rarely developed on PDA after 4 weeks of incubation and developed on dried Napier grasses within 1 week (Figure 2d,f). Conidiogenous cells were observed in pycnidia that developed on dried Napier grass (Figure 2g). Pycnidial conidia were aseptate, ellipsoidal to nearly fusiform, and 8.5-15.5 $\mu \mathrm{m}$ long $\times 3.5-5.7 \mu \mathrm{m}$ wide $(n=20$, 
av $=12.5 \pm 1.7 \times 4.7 \pm 0.6) \mu \mathrm{m}$ (Figure $2 \mathrm{~h}$ ). The fungal isolate was deposited in the Culture Collection of Pest Management, Faculty of Natural Resources, Prince of Songkla University Thailand, with accession number PSU-SC02.
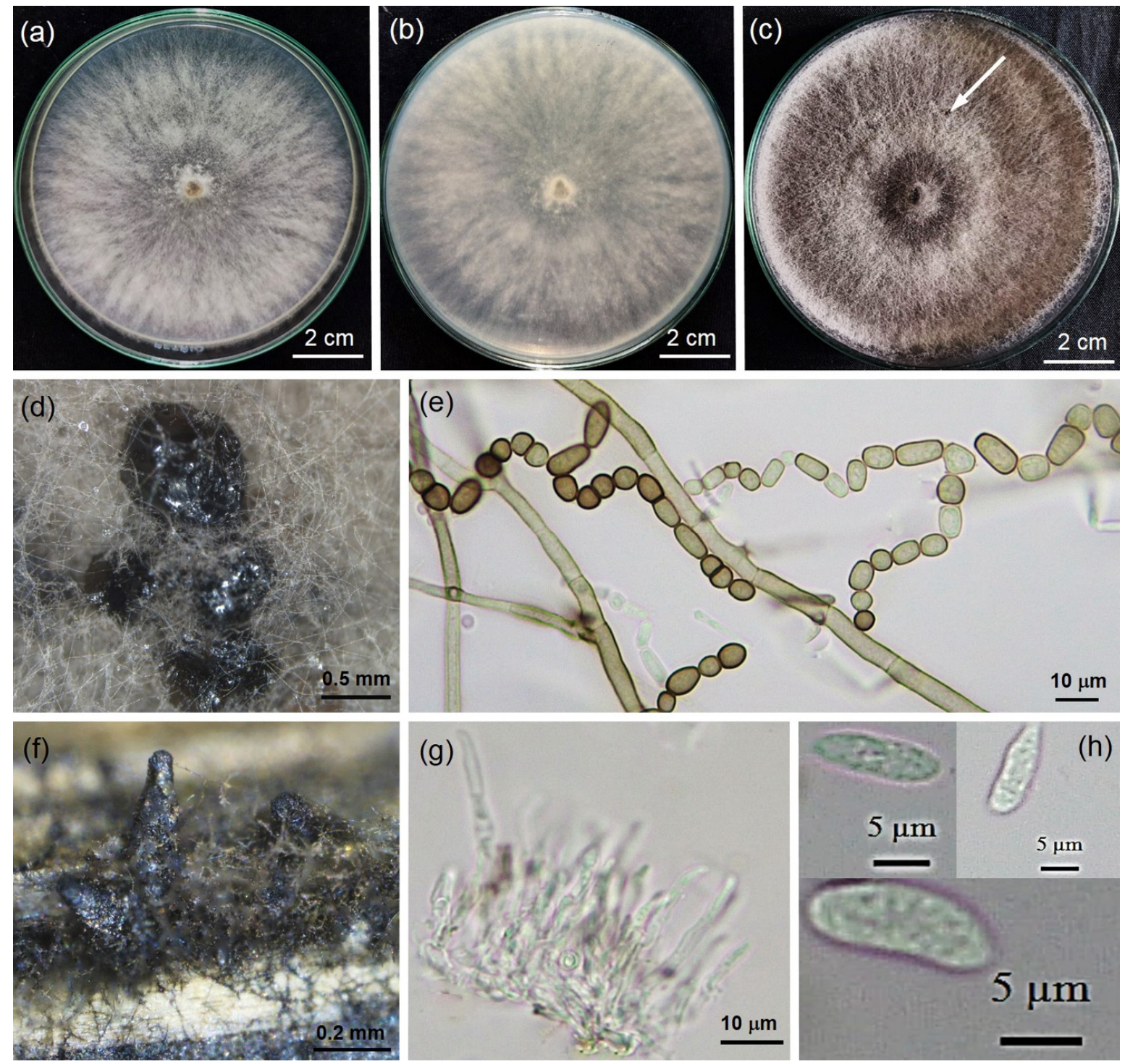

Figure 2. Morphological characteristics of PSU-SC02 on Hylocereus polyrhizus, 3-day-old colony on PDA in top (a) and bottom view (b), 4-week-old colony on PDA developed small black conidiomata ((c), arrow), zoom view of conidiomata (d), hyphae and arthroconidia (e), pycnidia developed on dried Napier grasses (f), conidiogenouse cells (g), and pycnidial conidia (h).

\subsection{Molecular Identification}

The PCR products of ITS, LSU, and tub were approximately 917, 1326, and 411 base pairs (bp) long, respectively. A BLAST search (https://blast.ncbi.nlm.nih.gov, accessed on 10 December 2021) revealed ITS, LSU, and $t u b$ sequences identical to those of Neoscytalidium dimidiatum, with $99.43 \%, 100 \%$, and $99.76 \%$ identity, respectively. The DNA sequences of ITS, LSU, and $t u b$ of PSU-SC02 were deposited in GenBank and acquired accession numbers LC660640, LC660641, and LC660642, respectively. The maximum likelihood (ML) tree of the combined DNA sequences of ITS, LSU, and $t u b$ showed that the PSU-SC02 isolate grouped in the same clade as N. dimidiatum CBS 251.49 (Figure 3). Therefore, fungal isolate PSU-SC02 was identified as $N$. dimidiatum. 


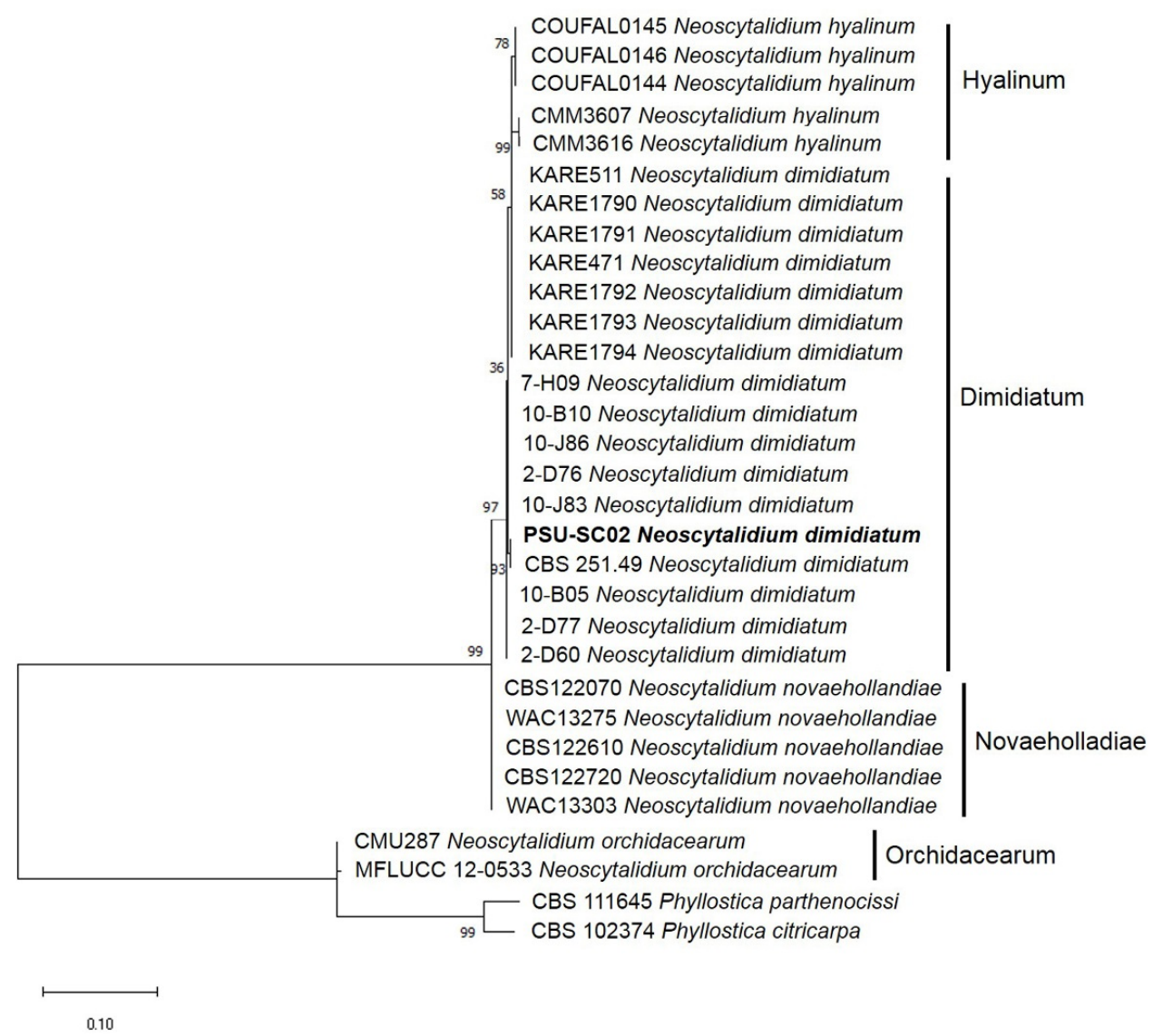

Figure 3. Phylogenetic tree of combined DNA sequences (ITS, LSU, and tub) of Neoscytalidium dimidiatum and related species acquired from Genbank constructed by maximum likelihood with 1000 bootstrap replications. Bold letters indicate the sample from this study. Phyllostica parthenocissi and $P$. citricarpa were used as out groups.

\subsection{Neoscytalidium dimidiatum Causing Stem Canker}

To fulfill Koch's postulates, a pathogenicity test was conducted on the stem of $H$. polyrhizus. Use of the agar plug method showed that $N$. dimidiatum PSU-SC02 caused cankers on healthy stems of $H$. polyrhizus after incubation in a moist box for 7 days (Figure 4). After 10 days of incubation, black pycnidia developed on the surface of $H$. polyrhizus, and the disease became severe when incubated for 14 days. Reisolation using the tissue transplanting method revealed that the morphology of the isolated fungus was similar to that of PSU-SC02.
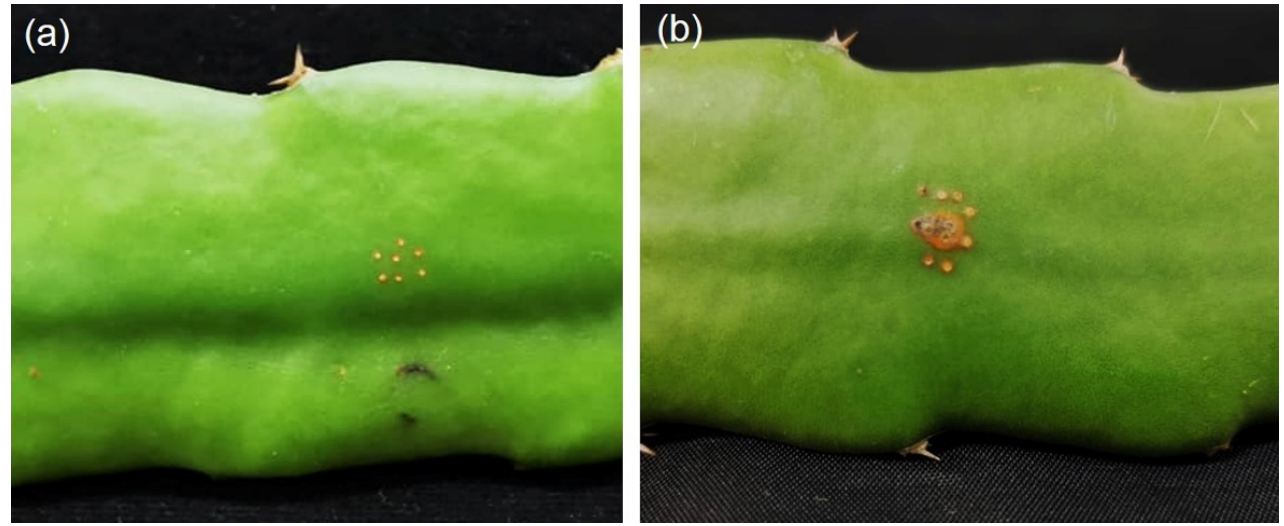

Figure 4. Pathogenicity test of Neoscytalidium dimidiatum PSU-SC02 on stem of Hylocereus polyrhizus, control (a), and PSU-SC02-inoculated stem (b). 


\section{Discussion}

Canker disease caused by Neoscytalidium species is considered the most destructive disease for dragon fruit plantations worldwide and affects dragon fruit production, resulting in losses of up to $60-80 \%$ of market value [18]. In this study, we used both morphological and molecular tools to identify fungal pathogens at the species level and pathogenicity tests to fulfill Koch's postulates. Based on morphology and phylogenetic analyses of ITS, LSU, and $t u b$ sequences in this study, the fungal pathogen causing stem canker on H. polyrhizus was identified as $N$. dimidiatum.

Neoscytalidium dimidiatum has been reported to be a fast-growing fungus that commonly reaches a diameter of $9 \mathrm{~cm}$ on Petri dishes within 3 days of incubation, as previously described by Mohd et al. [3] and Turkolmez et al. [19]. Our results are in agreement with previous research; the $N$. dimidiatum PSU-SC02 colony on PDA reached a diameter of $9 \mathrm{~cm}$ in 3 days. Arthroconidia of our strain (N. dimidiatum PSU-SC02) were diverse in size and shape, as previously reported for N. dimidiatum by Nouri et al. [20]. Pycnidia of $N$. dimidiatum have been observed on PDA with irregular shapes, singly or in aggregate after 4 weeks of incubation [20]; these characteristics were also observed in our study. Pycnidia was successfully developed on sterile dried grasses covered on WA (Figure 2f), as observed in previous studies [21]. Furthermore, N. dimidiatum PSU-SC02 from our study showed hyaline conidiogenous cells, and pycnidial conidia were aseptate, hyaline, and ellipsoidal to fusiform. These morphologies were typical of $N$. dimidiatum, as indicated by previous reports $[3,19,22]$.

To confirm the Neoscytalidium species at the species level, multiple DNA sequences of ITS, LSU, and $t u b$ were analyzed in this study. It is known that the identification of fungal pathogens relies on both morphology and molecular properties. Mohd et al. [3] used the morphology and single DNA sequence of ITS to identify $N$. dimidiatum as causing stem canker on H. polyrhizus in Malaysia. Huang et al. [23] studied the morphology and phylogeny of double DNA sequences of ITS and LSU to identify a new species of Neoscytalidium and named it N. orchidacearum. Furthermore, Nouri et al. [20] also used the morphology and multiple DNA sequences of ITS, translation elongation factor 1- $\alpha$ (tef1- $\alpha$ ), and $t u b$ to diagnose $N$. dimidiatum as causing canker, shoot blight, and fruit rot of almond in California. Based on our study, the morphology and molecular characteristics of ITS, LSU, and tub successfully identified Scytalidium-like fungi causing canker on H. polyrhizus as N. scytalidium.

Currently, fungi in the genus Neoscytalidium comprise four species, namely N. dimidiatum, $N$. hyalinum, $N$. novaehollandiae, and $N$. orchidacearum. N. dimidatum causes diseases in several plant species: canker of Ficus trees in Egypt [24]; root rot of sweet potato in Brazil [25]; shoot and needle blight of pines (Pinus spp.) in Turkey [26]; and shoot blight of citrus in Jordan [27]. Furthermore, N. dimidiatum has also been reported to cause canker on H. polyrhizus in Taiwan [28], Malaysia [3], and China [29]. However, there are no previous reports of $N$. dimidiatum causing canker on $H$. polyrhizus in Thailand. To our knowledge, this is the first report of $N$. dimidiatum as a fungal pathogen of canker on H. polyrhizus in Thailand.

\section{Materials and Methods}

\subsection{Sample Collection and Pathogen Isolation}

A total of ten symptomatic stem canker samples of $H$. polyrhizus were collected from a dragon fruit plantation field in Phatthalung Province, southern Thailand $\left(7^{\circ} 45^{\prime} 24.2^{\prime \prime} \mathrm{N}\right.$, $\left.99^{\circ} 58^{\prime} 47.2^{\prime \prime} \mathrm{E}\right)$, kept in a plastic bag in an ice box and taken to a plant pathology laboratory, where isolation was subsequently conducted. The isolation of fungal pathogens was conducted by tissue transplantation according to the method of Pornsuriya et al. [14]. Small pieces $(2-3 \mathrm{~mm}$ ) of infected tissue were surface disinfected with $0.5 \%$ sodium hypochlorite $(\mathrm{NaOCl})[13]$, rinsed three times with sterilized distilled water $(\mathrm{DW})$, air-dried, placed on water agar (WA), and incubated for $24 \mathrm{~h}$ at $28 \pm 2{ }^{\circ} \mathrm{C}$. Hyphal tips were cut and transferred to potato dextrose agar (PDA), incubated at ambient temperature $\left(28 \pm 2{ }^{\circ} \mathrm{C}\right)$ with natural light-light cycle and subsequently used for further methods. 


\subsection{Morphology Study}

The morphology of fungal colonies is determined by their ability to grow on PDA, with varied observations of colony traits, such as color, size, and shape. In this study, three plates were incubated at $28 \pm 2{ }^{\circ} \mathrm{C}$, and the diameters of colonies were measured daily until the colonies reached the edge of the plate. The growth rate per day on PDA of fungal isolates was calculated. The growth rate experiment was repeated twice. The general morphological characteristics of the fungal isolates were observed using a Leica S8AP0 stereomicroscope (Leica Microsystems, Wetzlar, Germany) with $10 \times$ magnification and a Leica DM750 compound microscope (Leica Microsystems, Wetzlar, Germany) with $40 \times$ magnification. Mycelial plugs $(0.5 \mathrm{~cm})$ were cut from the edges of 3-day-old colonies of fungal isolates and placed on WA covered with sterile dried Napier grasses as substrates to develop pycnidia structures according to previous studies [13,21].

\subsection{DNA Extraction and PCR Amplification}

Fungal isolates were cultured on PDA for 2 days and subjected to DNA extraction by the mini-preparation method [30]. DNA quantification was observed by $1 \%$ agarose gel electrophoresis. PCR amplification of internal transcribed spacer (ITS), nuclear large subunit (LSU), and $\beta$-tubulin ( $t u b$ ) was amplified by using ITS1/ITS4 [31], LR0R/LR5 [32], and $\mathrm{Bt} 2 \mathrm{a} / \mathrm{Bt} 2 \mathrm{~b}$ [33] primer pairs, respectively. The PCR mixture was composed of $20 \mathrm{pmol}$ of primers, DNA template, nuclease-free DW, and $2 \times$ OneTaq $^{\circledR} 2$ X PCR master mix with standard buffer (Biloabs, New England, MA, USA). The Thermal Cycler (Bio-Rad Laboratories, CA, USA) was run with the following settings: initial denaturation at $94{ }^{\circ} \mathrm{C}$ for $30 \mathrm{~s}$; 30 cycles of denaturation at $94{ }^{\circ} \mathrm{C}$ for $30 \mathrm{~s}$, annealing at $60^{\circ} \mathrm{C}$ for $60 \mathrm{~s}$; extension at $68^{\circ} \mathrm{C}$ for $1 \mathrm{~min}$; and final extension at $68^{\circ} \mathrm{C}$ for $5 \mathrm{~min}$. PCR products were stained with novel juice (GeneDireX, Taoyuan, Taiwan), separated by $1 \%$ agarose gel electrophoresis and observed on an LED Transilluminator (GeneDireX, Taoyuan, Taiwan).

PCR products were sequenced at the WARD MEDIC sequencing service in Thailand. The DNA sequences of ITS, LSU, and $t u b$ were searched for in the Blast program (National Center for Biotechnology Information, NCBI). The DNA sequences were aligned by Clustal $\mathrm{W}$, and a phylogenetic tree was constructed by MEGA X [34] with a maximum likelihood of 1000 bootstrap replications. DNA sequences of fungal isolates and related species were obtained from GenBank (Table 1) to construct the phylogenetic analyses. DNA sequences were deposited in GenBank to obtain accession numbers.

\subsection{Pathogenicity Test}

The fungal isolate was cultured on PDA for 7 days and subjected to inoculation of the stem of H. polyrhizus using the agar plug method [16]. Four stems of H. polyrhizus (4 replications) were prepared for inoculation, and the experiment was repeated twice. The stem of $\mathrm{H}$. polyrhizus was disinfected with $70 \%$ ethanol and wounded with fine needles $(0.5 \mathrm{~cm}$ in diameter). An agar plug of fungal isolate was cut from a 7-day-old colony and directly placed on wounded H. polyrhizus stems. Inoculation of PDA alone via agar plugs was used as a control. The inoculated samples were then incubated in a moist chamber to maintain humidity $(85 \% \mathrm{RH}), 28 \pm 2{ }^{\circ} \mathrm{C}$, with a natural light-dark cycle for 7 days. The development of canker was observed and photographed. Infected tissue samples were reisolated via the tissue transplanting method as described in Section 4.1, and morphology was observed via microscopy as explained in Section 4.2. 
Table 1. DNA sequences used to generate a phylogenetic tree acquired from GenBank with accession numbers.

\begin{tabular}{|c|c|c|c|c|c|}
\hline \multirow{2}{*}{ Taxa } & \multirow{2}{*}{ Isolate } & \multirow{2}{*}{ Host, Region } & \multicolumn{3}{|c|}{ Accession Numbers } \\
\hline & & & ITS & LSU & $t u b$ \\
\hline \multirow[t]{17}{*}{$\begin{array}{l}\text { Neoscytalidium } \\
\text { dimidiatum }\end{array}$} & 2-D60 & Ficus carica, USA & MG021571 & - & MG021514 \\
\hline & 2-D76 & Prunus dulcis, USA & MG021583 & - & MG021480 \\
\hline & 2-D77 & P. dulcis, USA & MG021584 & - & MG021481 \\
\hline & 7-H09 & P. dulcis, USA & MG021587 & - & MG021484 \\
\hline & 10-B05 & P. dulcis, USA & MG021589 & - & MG021486 \\
\hline & 10-B10 & P. dulcis, USA & MG021591 & - & MG021488 \\
\hline & 10-J83 & P. dulcis, USA & MG021595 & - & MG021492 \\
\hline & 10-J86 & P. dulcis, USA & MG021596 & - & MG021493 \\
\hline & CBS 251.49 & Juglans regia, USA & KF531819 & DQ377923 & FM211166 \\
\hline & KARE471 & P. dulcis, USA & MG021601 & - & MG021498 \\
\hline & KARE511 & P. dulcis, USA & MG021608 & - & MG021505 \\
\hline & KARE1790 & P. dulcis, USA & MG021578 & - & MF991145 \\
\hline & KARE1791 & P. dulcis, USA & MG021579 & - & MG021476 \\
\hline & KARE1792 & Prunus dulcis, USA & MG021580 & - & MG021477 \\
\hline & KARE1793 & P. dulcis, USA & MG021581 & - & MG021478 \\
\hline & KARE1794 & P. dulcis, USA & MG021582 & - & MG021479 \\
\hline & PSU-SC02 * & $\begin{array}{c}\text { Hylocereus polyrhizus, } \\
\text { Thailand }\end{array}$ & LC660640 & LC660641 & LC660642 \\
\hline \multirow[t]{5}{*}{ N. hyalinum } & СММ3607 & Jatropha curcas, Brazil & KF234542 & - & KF254925 \\
\hline & СММ3616 & J. curcas, Brazil & JQ927342 & - & KF254931 \\
\hline & COUFAL0144 & Nopalea cochenillifera, Brazil & MH251953 & - & MH251969 \\
\hline & COUFAL0145 & N. cochenillifera, Brazil & MH251954 & - & MH251970 \\
\hline & COUFAL0146 & N. cochenillifera, Brazil & MH251955 & - & MH251971 \\
\hline \multirow[t]{5}{*}{ N. novaehollandiae } & CBS 122070 & Grevillea agrifolia, Australia & - & - & MT592759 \\
\hline & CBS 122072 & Adansonia gregorii, Australia & - & - & MT592761 \\
\hline & CBS 122610 & Acacia synchronicia, Australia & - & - & MT592762 \\
\hline & WAC13275 & Mangifera indica, Australia & GU172400 & - & - \\
\hline & WAC13303 & M. indica, Australia & GU172398 & - & - \\
\hline \multirow[t]{2}{*}{ N. orchidacearum } & CMU287 & Cattleya sp., Thailand & KY933091 & KY933092 & - \\
\hline & MFLUCC 12-0533 & Orchidaceae, Thailand & KU179865 & KU179864 & - \\
\hline Phyllostica citricarpa & CBS 102374 & Citrus aurantium, Brazil & FJ538313 & DQ377877 & - \\
\hline Phyllostica parthenocissi & CBS 111645 & Parthenocissus quinquefolia, USA & EU683672 & - & - \\
\hline
\end{tabular}

* Bold letters indicate samples from this study.

\section{Conclusions}

Herein, we identified the fungal pathogen causing stem canker in $H$. polyrhizus in Thailand. Based on the morphological characteristics and molecular properties of multiple DNA sequences of ITS, LSU, and $t u b$, the pathogenicity tests revealed that the fungal pathogen $N$. dimidiatum caused stem canker in $H$. polyrhizus. Knowledge of the diagnosis of plant diseases is important for disease control and management. In order to determine and verify appropriate methods to manage stem canker disease on $H$. polyrhizus plants, further studies are needed in the near future.

Author Contributions: Conceptualization, K.S.D. and A.S.; methodology, K.S.D.; software, K.S.D.; validation, P.W., C.P. and A.S.; formal analysis, K.S.D.; investigation, K.S.D.; resources, A.S.; data curation, A.S.; writing — original draft preparation, K.S.D.; writing-review and editing, P.W., C.P. and A.S.; visualization, A.S.; supervision, A.S.; project administration, A.S.; funding acquisition, A.S. All authors have read and agreed to the published version of the manuscript.

Funding: This research was funded by the National Science, Research and Innovation Fund (NSRF) and Prince of Songkla University (Grant No. NAT6505003M and NAT6505003b).

Institutional Review Board Statement: Not applicable. 
Informed Consent Statement: Not applicable.

Data Availability Statement: The DNA sequences data obtained in this study have been deposited in GenBank with accession numbers for ITS (LC660640), LSU (LC660641), and tub (LC660642).

Acknowledgments: The authors would like to give special thanks to Prince of Songkla University and the Center of Excellence in Agricultural and Natural Resources Biotechnology (CoE-ANRB) phase 3, Faculty of Natural Resources, Prince of Songkla University.

Conflicts of Interest: The authors declare no conflict of interest.

\section{References}

1. Blancke, R. Tropical Fruits and Other Edible Plants of the World: An Illustrated Guide; Cornell University Press: Ithaca, NY, USA, 2016.

2. Masyahit, M.; Sijam, K.; Awang, Y.; Satar, M.G.M. First report on bacterial soft rot disease on dragon fruit (Hylocereus spp.) caused by Enterobacter cloacae in Peninsular Malaysia. Int. J. Agric. Biol. 2009, 11, 659-666.

3. Mohd, M.H.; Salleh, B.; Zakaria, L. Identification and molecular characterizations of Neoscytalidium dimidiatum causing stem canker of red-fleshed dragon fruit (Hylocereus polyrhizus) in Malaysia. J. Phytopathol. 2013, 161, 841-849. [CrossRef]

4. Van, H.N.; Hieu, N.T.; Hanh, T.T.M.; Uyen, D.T.K.; Dien, L.Q. Emerging infectious diseases and insect pests of dragon fruit, passionfruit, citrus, longan. Management 2016, 1,630.

5. Nguyen, H.T.; Nguyen, H.V. Management strategies of major pitaya diseases in Vietnam. Management 2015, 473, $129-142$.

6. Ruangwong, O.-U.; Kunasakdakul, K.; Wonglom, P.; Dy, K.S.; Sunpapao, A. Morphological and molecular studies of a rare mucoralean species causing flower rot in Hylocereus polyrhizus. J. Phytopathol. 2022, 1-7. [CrossRef]

7. Saradhuldhat, P.; Kaewsongsang, K.; Suvittawat, K. Induced off-season flowering by supplemented fluorescent light in dragon fruit (Hylocereus undatus). J. Int. Soc. Southeast Asian Agric. Sci. 2009, 15, 0859-3132.

8. Wonglom, P.; Thithuan, N.; Bunjongsiri, P.; Sunpapao, A. Plant-parasitic algae (Cephaleuros spp.) in Thailand, including four new records. Pac. Sci. 2018, 72, 363-371. [CrossRef]

9. Thithuan, N.; Bunjonsiri, P.; Sunpapao, A. Morphology and behavior of gametes and zoospores from the plant-parasitic green algae, Cephaleuros (Chlorophyta, Ulvophyceae). Pac. Sci. 2019, 73, 403-410. [CrossRef]

10. Chairin, T.; Pornsuriya, C.; Thaochan, N.; Sunpapao, A. Corynespora cassiicola causes leaf spot disease on lettuce (Lactuca sativa) cultivated in hydroponic systems in Thailand. Australas. Plant Dis. Notes 2017, 12, 16. [CrossRef]

11. Pornsuriya, C.; Ito, S.; Sunpapao, A. First report of leaf spot on lettuce caused by Curvularia aeria. J. Gen. Plant Pathol. 2018, 84, 296-299. [CrossRef]

12. Nuangmek, W.; Aiduang, W.; Suwannarach, N.; Kumla, J.; Lumyong, S. First report of gummy stem blight caused by Stagonosporopsis cucurbitacearum on cantaloupe in Thailand. Can. J. Plant Pathol. 2018, 40, 306-311. [CrossRef]

13. Daengsuwan, W.; Wonglom, P.; Sunpapao, A. First report of Lasiodiplodia theobromae causing spadix rot in Anthurium andraeanum. J. Phytopathol. 2020, 168, 129-133. [CrossRef]

14. Pornsuriya, C.; Chairin, T.; Thaochan, N.; Sunpapao, A. Identification and characterization of Neopestalotiopsis fungi associated with a novel leaf fall disease of rubber trees (Hevea brasiliensis) in Thailand. J. Phytopathol. 2020, 168, 416-427. [CrossRef]

15. Wonglom, P.; Sunpapao, A. Fusarium incarnatum is associated with postharvest fruit rot of muskmelon (Cucumis melo). J. Phytopathol. 2020, 168, 204-210. [CrossRef]

16. Daengsuwan, W.; Wonglom, P.; Arikit, S.; Sunpapao, A. Morphological and molecular identification of Neopestalotiopsis clavispora causing flower blight on Anthurium andraeanum in Thailand. Hortic. Plant J. 2021, 7, 573-578. [CrossRef]

17. Suwannarach, N.; Khuna, S.; Kumla, J.; Cheewangkoon, R.; Suttiprapan, P.; Lumyong, S. Morphology Characterization, Molecular Identification, and Pathogenicity of Fungal Pathogen Causing Kaffir Lime Leaf Blight in Northern Thailand. Plants 2022, 11, 273. [CrossRef]

18. Hong, C.F.; Gazis, R.; Crane, J.H.; Zhang, S. Prevalence and epidemics of Neoscytalidium stem and fruit canker on pitahaya (Hylocereus spp.) in South Florida. Plant Dis. 2020, 104, 1433-1438. [CrossRef] [PubMed]

19. Turkolmez, S.; Derviş, S.; Ciftci, O.; Serce, C.U.; Dikilitas, M. New disease caused by Neoscytalidium dimidiatum devastates tomatoes (Solanum lycopersicum) in Turkey. Crop Prot. 2019, 118, 21-30. [CrossRef]

20. Nouri, M.T.; Lawrence, D.P.; Yaghmour, M.A.; Michailides, T.J.; Trouillas, F.P. Neoscytalidium dimidiatum causing canker, shoot blight and fruit rot of almond in California. Plant Dis. 2018, 102, 1638-1647. [CrossRef]

21. Pipattanapuckdee, A.; Boonyakait, D.; Tiyayon, C.; Seehanam, P.; Ruangwong, O. Lasiodiplodia pseudotheobromae causes postharvest fruit rot on longan in Thailand. Australas. Plant Dis. Notes 2019, 14, 21. [CrossRef]

22. Yi, R.H.; Mo, J.J.; Wu, F.F.; Chen, J. Fruit internal brown rot caused by Neoscytalidium dimidiatum on pitahaya in Guangdong province, China. Australas. Plant Dis. Notes 2015, 10,1-4. [CrossRef]

23. Huang, S.K.; Tangthirasunun, N.; Phillips, A.J.; Dai, D.Q.; Wanasinghe, D.N.; Wen, T.C.; Kang, J.C. Morphology and phylogeny of Neoscytalidium orchidacearum sp. nov. (Botryosphaeriaceae). Mycobiology 2016, 44, 79-84. [CrossRef] [PubMed]

24. Al-Bedak, O.A.; Mohamed, R.A.; Seddek, N.H. First detection of Neoscytalidium dimidiatum associated with canker disease in Egyptian Ficus trees. For. Pathol. 2018, 48, e12411. [CrossRef]

25. Mello, J.F.; Brito, A.C.Q.; Motta, C.M.S.; Vieira, J.C.B.; Michereff, S.J.; Machado, A.R. First report of Neoscytalidium dimidiatum causing root rot in sweet potato in Brazil. Plant Dis. 2019, 103, 373-374. [CrossRef] 
26. Turkolmez, S.; Dervis, S.; Ciftci, O.; Dikilitas, M. First report of Neoscytalidium dimidiatum causing shoot and needle blight of pines (Pinus spp.) in Turkey. Plant Dis. 2019, 103, 2960-2961. [CrossRef]

27. Alananbeh, K.M.; Al-Qasim, M.; Gharaibeh, A.; Al-Hiary, H.A. First report of shoot blight caused by Neoscytalidium dimidiatum on citrus in Jordan. Plant Dis. 2020, 104, 571. [CrossRef]

28. Chuang, M.F.; Ni, H.F.; Yang, H.R.; Shu, S.L.; Lai, S.Y.; Jiang, Y.-L. First report of stem canker disease of pitaya (Hylocereus undatus and Hylocereus polyrhizus) caused by Neoscytalidium dimidiatum in Taiwan. Plant Dis. 2012, 96, 906. [CrossRef]

29. Xu, M.; Peng, Y.; Qi, Z.; Yan, Z.; Yang, L.; He, M.-D.; Li, Q.-X.; Liu, C.-L.; Ruan, Y.-Z.; Wei, S.-S.; et al. Identification of Neoscytalidium dimidiatum causing canker disease of pitaya in Hainan, China. Australas. Plant Pathol. 2018, 47, 547-553. [CrossRef]

30. Saitoh, K.; Togashi, K.; Arie, T.; Teraoka, T. A simple method for a mini-preparation of fungal DNA. J. Gen. Plant Pathol. 2006, 72, 348-350. [CrossRef]

31. White, T.J.; Bruns, T.; Lee, S.; Tayler, J. Amplification and direct sequencing of fungal ribosomal RNA genes for phylogenies. In PCR Protocols: A Guide to Methods and Applications; Innis, A.M., Gelfelfard, D.H., Snindky, J.J., White, T.J., Eds.; Academic Press: San Diego, CA, USA, 1990; pp. 315-322.

32. Vilgalys, R.; Hester, M. Rapid genetic identification and mapping of enzymatically amplified ribosomal DNA from several Cryptococcus species. J. Bacteriol. 1990, 172, 4239-4246. [CrossRef]

33. Glass, N.L.; Donaldson, G.C. Development of primer sets designed for use with the PCR to amplify conserved genes from filamentous ascomycetes. Appl. Environ. Microbiol. 1995, 61, 1323-1330. [CrossRef] [PubMed]

34. Kumar, S.; Stecher, G.; Li, M.; Knyaz, C.; Tamaru, K. MEGA X: Molecular evolutionary genetics analysis across computing platforms. Mol. Biol. Evol. 2018, 35, 1547-1549. [CrossRef] [PubMed] 